\title{
Comparative Study of Combustible Species for 4-stroke Otto Cycle Combustion Motor and 6-stroke MUB-2 Cycle Combustion Motor with Fuel Pertamax
}

\section{Studi Komparasi Kadar Combustible Species Motor Bakar 4 tak Siklus Otto dan Motor Bakar 6 tak Siklus MUB-2 Berbahanbakar Pertamax}

\author{
Dedi Nurdiansyah $^{1}$, Sudjito Soeparman ${ }^{2}$, Eko Siswanto ${ }^{3}$ \\ \{dedymutiabondan@gmail.com¹, sudjitospn@ub.ac.id²,eko_s112@ub.ac.id ${ }^{3}$ \} \\ Teknik Mesin, Universitas Brawijaya Malang ${ }^{1,2.3}$
}

\begin{abstract}
This paper describes the ratio of levels of combustible species (CO, $\mathrm{HC}, \mathrm{CO} 2$ and lambda) of a four-cycle otto motor with a six-stroke MUB-2 motor with additional combustion duration and two working steps. The increase in combustion duration aims to re-burn combustible species that have not been completely burned in the first combustion. This study used a 4 stroke motor with a capacity of $125 \mathrm{cc}$ and then modified it into a 6 stroke motorbike with twice the duration of combustion. The observed local atmospheric conditions at a relative humidity of about $76 \% \mathrm{rH}$, and the ambient temperature and pressure were around $24{ }^{\circ} \mathrm{C}$ and $101.32 \mathrm{kPa}$, respectively. The implementation of data retrieval with crankshaft rotation at intervals of $600 \mathrm{rpm}$ from $2400 \mathrm{rpm}$ to $7200 \mathrm{rpm}$.Using an anlyser gas, the MUB-2 six-stroke engine showed $12.36 \%$ CO levels, $27.30 \%$ HC levels, $30.8 \mathrm{CO}$ levels \% and $1.7 \%$ lower lambda than conventional four-stroke engines. This means that in the 6 stroke MUB-2 motor, the combustion process of the air and fuel mixture is more perfect than the conventional 4 stroke motor.
\end{abstract}

Keywords - stroke; combustible species; combustion

\begin{abstract}
Abstrak. Makalah ini memaparkan tentang perbandingan kadar combustible species (CO,HC,CO2 dan lambda) motor empat tak siklus otto dengan motor bakar enam tak siklus MUB-2 dengan tambahan durasi pembakaran dan dua langkah kerja. Peningkatan durasi pembakaran bertujuan untuk membakar kembali combustible species yang belum terbakar sempurna pada pembakaran pertama. Penelitian ini menggunakan motor 4 tak berkapasitas 125 cc kemudian dimodifikasi menjadi motor 6 tak dengan dua kali durasi pembakaran. Pengamatan kondisi atmosfir lokal pada kelembaban relatif sekitar $76 \% \mathrm{rH}$, dan suhu dan tekanan sekitar masing-masing sekitar $24{ }^{\circ} \mathrm{C}$ dan $101.32 \mathrm{kPa}$. Pelaksanaan pengambilan data dengan putaran poros engkol dengan interval 600 rpm dari putaran 2400 rpm sampai dengan 7200 rpm.menggunakan gas anlyser, mesin enam tak MUB-2 menunjukkan kadar CO 12,36\%, kadar HC 27,30\%, kadar CO2 30,8\% dan lambda 1,7\% lebih rendah daripada mesin empat tak konvensional. Artinya, pada motor 6 tak MUB-2 proses pembakaran campuran udara dan bahan bakar lebih sempurna daripada motor bakar 4 tak konvensional.
\end{abstract}

Kata Kunci - langkah; combustible species; pembakaran

\section{Pendahuluan}

Motor bakar bensin siklus otto 4 tak dengan berbagai macam kelebihan memiliki kekurangan, salah satunya adalah pada saat motor 4 tak disaat bekerja diatas 3000 rpm kesempatan mixing dan difusi antara bahan bakar dan udara adalah 0,01 detik, sehingga kesempatan mixing antara bahan bakar dan udara sangat minim mengakibatkan pembakaran di dalam ruang bakar tidak sempurna. Hal tersebut dapat dilihat dari Tingginya nilai combustible spesies ( $\mathrm{HC}, \mathrm{CO}, \mathrm{CO} 2$ dan lambda ). Pada tahun 2019 telah diteliti tentang nilai combustible species dari motor bensin 4 tak berbahan bakar bakar pertamax. Dari hasil uji emisi gas buang dengan menggunakan gas analyzer mendapatkan kadar CO (karbon monoksida) sebesar 5,30\% dan mendapatkan kadar HC (Hidro Karbon) sebesar $825,33 \mathrm{ppm}$. Kadar combustible species yang tinggi berpengaruh terhadap unjuk kerja mesin, sehingga efisiensi dan dayanya akan menurun. [1]

Siswanto at al (2017) melakukan penelitian motor bakar 6 tak dengan memodifikasi motor bakar 4 tak buatan Honda $125 \mathrm{cc}$ dimana terdapat penambahan 2 langkah yaitu 1 langkah ekspansi dan 1 langkah kompresi, serta secara otomaris menambah 1 durasi langkah pembakaran, Pada langkah buang yang seharusnya katup buang terbuka dan membuang sisa hasil pembakaran, pada motor 6 tak ini dikondisikan kedua katup tertutup, sehingga yang seharusnya langkah buang menjadi langkah kompresi mengkompresi sisa hasil pembakaran. Pada saat piston menuju titik mati atas busi menyala dan membakar kembali sisa bahan bakar untuk dirubah menjadi langkah kerja yang bertujuan untuk meningkatkan performa mesin. Motor 6 tak yang dikembangkan di atas di kenal dengan motor 6 tak MUB-2. [2] 


\section{Motor Bakar 4 tak Siklus Otto}

Motor bakar 4 tak otto atau yang sering disebut motor bensin adalah salah satu dari internal combustin engine dimana pada motor 4 tak piston akan bergerak dari Titik Mati Atas (TMA) ke Titik Mati Bawah (TMB), dimana setiap kali bergerak dari TMA ke TMB maupun dari TMB ke TMA terhitung satu kali langkah. Oleh karena itu pada motor bakar 4 tak setiap siklusnya terjadi empat kali gerakan torak dalam dua kali putaran poros engkol dan menghasilkan satu langkah kerja. [3]

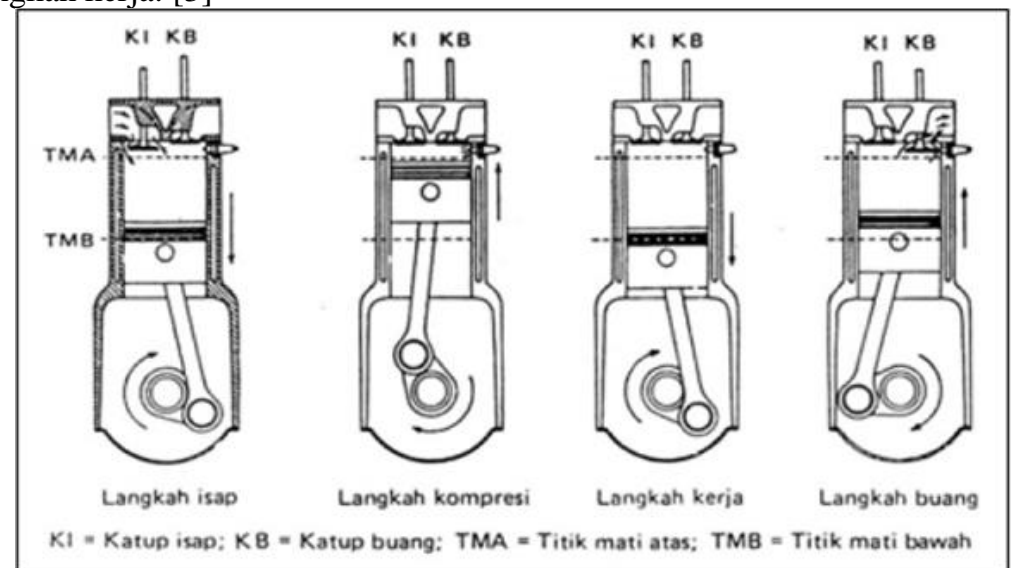

Gambar 1 Skema langkah kerja motor bensin 4 tak

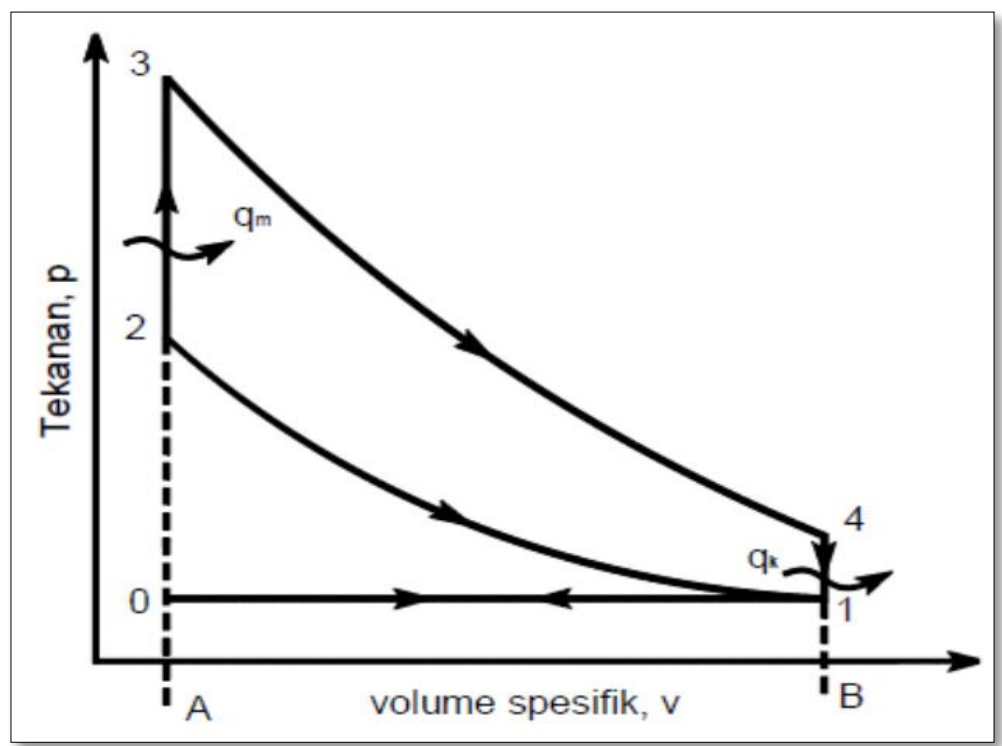

Gambar 2 Skema siklus otto ideal

1. Proses $0-1:$ Langkah isap/pengisian secara isobaric (tekanan=konstan)

2. Proses $1-2$ : Langkah kompresi/tekan secara isentropic (entopi=konstan)

Proses 2-3: Proses pemasukan kalor secara isokhorik (volume=konstan)

3. Proses 3-4 : Langkah kerja/ekspansi secara isentropic (entropi=konstan)

Proses 4-1: Proses pelepasan kalor secara isokhorik (volume=konstan)

4. Proses 1-0: Langkah buang/ kompresi isobarik (tekanan=konstan)

\section{Motor Bakar 6 Tak Siklus MUB-2}

Motor 6 tak MUB-2 ini adalah motor bakar hasil modifikasi dari motor 4 tak bensin, dengan menambah 2 langkah kompresi dan kerja disertai dengan pembakaran kembali sisa-sisa bahan bakar yang belum terbakar sempurna untuk dirubah menjadi tenaga. Pada Proses ini katup buang pada saat langakh buang yang seharusnya terbuka dikondisikan tertutup sehingga sisa-sisa bahan bakar terkompresi kembali. Pada saat Piston bergerak sebelum akhir langkah kompresi busi membakar sisa-sisa pembakaran kembali dan merubahnya menjadi energy mekanik untuk melakuakan ekspansi langkah kerja. Proses 4 langkah dirubah menjadi 6 langkah perlu beberapa modifikasi, yaitu mengubah timing perbandingan putaran poros camesaft dan poros cranksaft. Pada motor 4 tak, perbandingan putaran cranksaft dan camesaft adalah $2: 1$ dimana dua kali putaran poros cranksaft satu kali putaran 
poros camesaft. Pada motor 6 tak perbandingan putaran cranksaft dan camesaft adalah $3: 1$ dimana tiga kali putaran poros cranksaft satu kali putaran poros camesaft. [4]

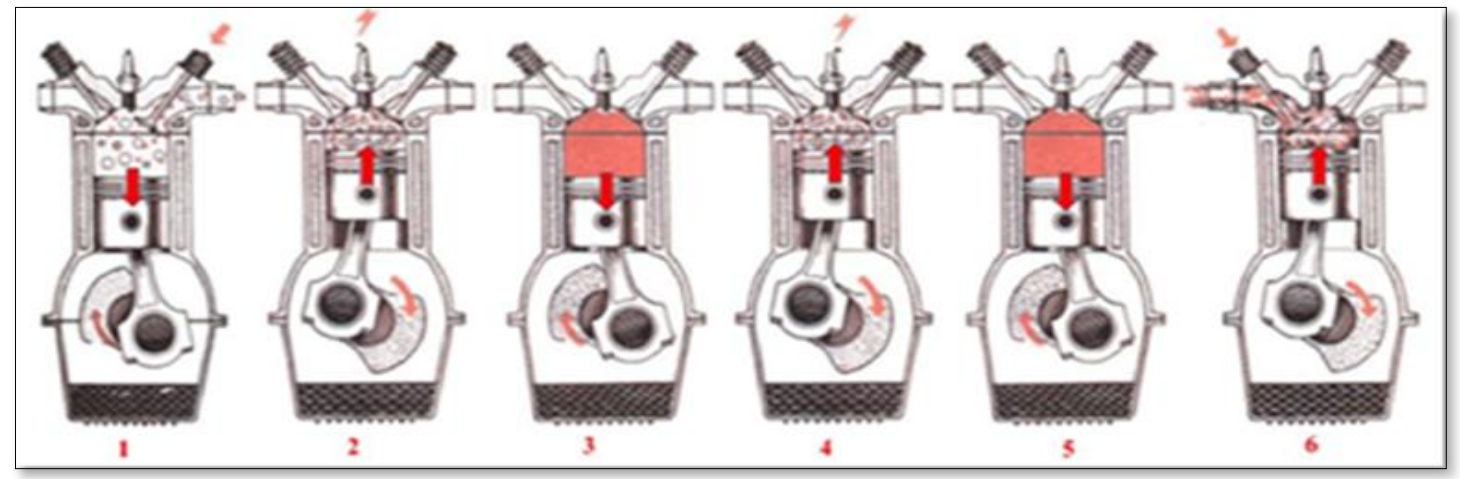

Gambar 3 Mekanisme langkah Motor bakar 6 tak MUB-2

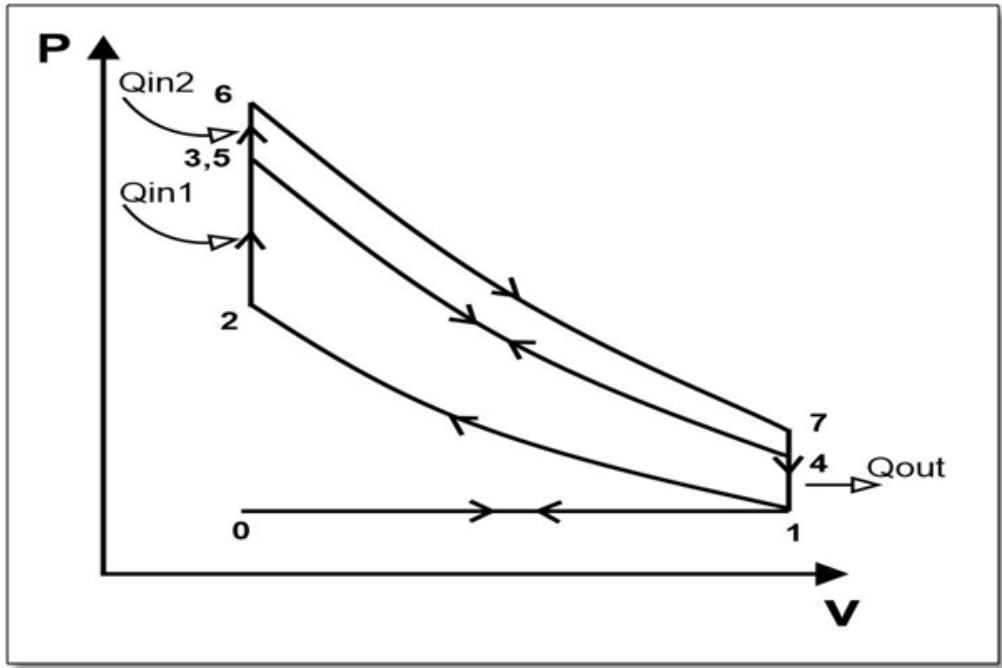

Gambar 4 Skema Siklus idela Motor bakar 6 tak MUB-2

1. $\quad(0-1)=$ Langkah hisap (isobarik)

2. $\quad(1-2)=$ Langkah kompresi 1 (isentropik)

$(2-3)=$ Pemasukan kalor I/Qin 1 (isokhorik)

3. $\quad(3-4)=$ Langkah ekspansi 1 (isentrokik)

4. $\quad(4-5)=$ Langkah kompresi 2 (isentropik)

(5-6) $=$ Pemasukan kalor 2/Qin 2 (isokhorik)

5. $\quad(6-7)=$ Langkah ekspansi 2 (isentropik)

$(7-1)=$ Pelepasan kalor/Qout (isokhorik)

6. (1-0) = Langkah buang (isobarik)

\section{Karburator}

Karburator adalah spare part pada motor bakar yang berfungsi untuk membuat campuran udara dan bahan bakar pada perbandingan campuran yang tepat ke ruang pembakaran. Pada gambar 2.13 dijelaskan tentang prinsip dari penyemburan. Sebagai akibat dari derasnya tiupan angin di (a), suatu kondisi vacum (tekanan dibawah atmosfir) terjadi di (b). Perbedaan tekanan antara vacum dan atmosfir udara di (c) mengakibatkan semburan terjadi pada gasoline (b). Berdasarkan proses ini, maka semakin cepat aliran udara (a) mengakibatkan semakin besar vacum yang terjadi pada (b), dan semakin banyak gasoline yang disemprotkan / disemburkan. [5]

\section{Pertamax}

Pertamax merupakan jenis bahan bakar dengan angka oktan 92. Pertamax dianjurkan digunakan untuk kendaraan bahan bakar bensin yang mempunyai perbandingan kompresi tinggi (9,1 : 1 sampai 10,0 : 1). Bensin dengan bilangan oktana tinggi mempunyai periode penundaan yang panjang Pertamax adalah bahan bakar yang memiliki 
angka oktan (RON) minimal 92,0 diperuntukkan untuk mesin kendaraan yang mempunyai rasio kompresi antara 9:1 s.d. 10:1. Pertamax diproduksi oleh pertamina sesuai dengan keputusan Direktorat Jenderal Minyak dan Gas Bumi No. 3674/K24/DJM/2006 tanggal 17 Maret 2006 tentang spesifikasi Bahan Bakar Minyak jenis bensin 92.[6]

\section{Emisi Gas Buang}

Emisi gas buang adalah polutan dan gas sisa dari proses oksidasi atau pembakaran yang terjadi di dalam ruang bakar yang dikeluarkan melalui sistem ekshoust pada mesin,sedangkan definisi dari proses pembakaran adalah reaksi pembakaran atau oksidasi antara oksigen $(\mathrm{O} 2)$ di udara dengan senyawa hidrokarbon (HC) yang terkandungpada bahan bakar untuk menghasilkan tenaga. Dalam reaksi pembakaran yang sempurna, sisa hasil pembakaran adalah berupa gas buang yang mengandung karbondioksida(CO2), uap air (H2O), Oksigen $(\mathrm{O} 2)$ dan Nitrogen (N2).Secara aktual, proses pembakaran yang terjadi di dalam mesin kendaraan tidak selalu berjalan sempurna sehingga di dalam gas buang mengandung senyawa gas-gas polutan seperti karbonmonoksida (CO), hidrokarbon (HC), Nitrogenoksida (NOx) dan partikulat.[7]

Negara Republik indonesia memiliki aturan yang mengatur tentang pengendalian dan batas emisi gas buang pada kendaraan bermotor. Peraturan tersebut tercantum pada peratutan perundang undangan Mentri Negara Lingkungan Hidup Republik Indonesia No.23 Tahun 2012 tentang Baku Mutu emisi gas buang kendaraan bermotor tepe baru kategori L3.[8]

Tabel 1 Batas Emisi Gasbuang Kendaraan Bermotor KepMen LH No 23 Th 2012

\begin{tabular}{lllll}
\hline No & Kategori & Parameter & $\begin{array}{l}\text { Nilai Ambang Batas } \\
\mathbf{( g / k m})\end{array}$ & Metode Uji \\
\hline & & CO & 2,0 & ECE R 40 \\
1. & L3 $<150 \mathrm{~cm}^{3}$ & HC & 0,8 & UDC mode \\
& & NOx & 0,15 & (Cold start) \\
& & CO & 2,0 & ECE R 40 \\
2. & \multirow{2}{*}{ L3 $2150 \mathrm{~cm} 3$} & HC & 0,3 & UDC mode \\
& & NOx & 0,15 & (Cold start) \\
\hline
\end{tabular}

\section{Combustible Species}

\section{Hidrocarbon $(\mathrm{HC})$}

Kadar hidrokarbon yang tinggi pada emisi gas buang disebabkan campuran yang kaya, biasanya terjadi pada rpm rendah. Pada rpm rendah, saat pengapian akan cenderung dimundurkan sehingga pembakaran terlambat menyebabkan ada sebagian bahan bakar tidak terbakar dengan sempurna. Bentuk ruang bakar yang begitu rumit akan sulit dijangkau oleh api dari busi, menyebabkan sulitnya proses pembakaran. Bahan bakar yang tidak terbakar akan keluar bersama gas buang sehingga konsentrasi HC menjadi tinggi. [9].

2. Karbonmonoksida (CO)

Pembakaran tidak sempurna akan melepas HC yang tidak terbakar dan menghasilkan CO yang berbahaya bagi kesehatan. Kadar CO yang tinggi pada emisi gas buang disebabkan oleh campuran kaya, yang terjadi pada rpm rendah, karena pada rpm rendah, pengapian cenderung dimundurkan sehingga pembakaran terlambat yang menyebabkan sebagian unsur $\mathrm{C}$ dan $\mathrm{O}$ tidak berubah menjadi $\mathrm{CO}$ 2. Rendahnya temperatur pembakaran juga mempengaruhi terbentuknya gas $\mathrm{CO}$, karena suhu yang dibutuhkan untuk membentuk $\mathrm{CO} 2$ lebih besar dari pada pembentukan $\mathrm{CO}$ yang menyebabkan emisi mengandung kadar CO yang tinggi. [9]

\section{Karbondioksida $(\mathrm{CO} 2)$}

Karbon dioksida $(\mathrm{CO} 2)$ adalah jenis gas tidak berwarna dan tidak berbau terdiri dari atom oksigen yang terikat secara kovalen dengan satu atom karbon. $\mathrm{CO} 2$ berbentuk gas pada keadaan tertentu dan tekanan standar. Kandungan $\mathrm{CO} 2$ di atmosfer bervariasi antara 0,03\% (300 ppm) bergantung pada lokasi dimana gas CO2 tersebut dihasilkan. Gas karbon dioksida hasil pembakaran ini adalah gas yang menjadi polutan yang menyebabkan pemanasan global di bumi [10]

\section{Lambda $(\lambda)$}

Lambda $(\lambda)$ adalah persen udara berlebih, Hal tersebut dipengaruhi dari lingkungan maupun bentuk kontruksi dari sparepart pembakaran. untuk mengantisipasi permasalahan ini dengan mendisplai udara berlebih, dari ini muncul istilah lain dari udara teoritis. Secara teoritis dapat diartikan bahwa nilai lamda jika lambda = 1 merupakan campuran ideal, pada kondisi actual sama dengan yang tersebut sesuai dengan teori stoikiometri. Lambda > 1, merupakan campuran kurus, disebabkan karena jumlah presentase udara lebih banyak daripada bahan bakar. Lambda $<1$, merupakan campuran gemuk, disebabkan karena jumlah prrosentase udara lebih sedikit dibandingkan dengan bahan bakar. [10] 


\section{METODE}

\section{Variabel Bebas}

Variabel bebas dalam penelitian ini adalah putaran poros engkol dengan interval $600 \mathrm{rpm}$ dari putaran $2400 \mathrm{rpm}$ sampai dengan $7200 \mathrm{rpm}$.

\section{Variabel Terikat}

variabel yang terikat dalam penelitian ini adalah emisi gas buang.

\section{Variabel Terkontrol}

Dalam penelitian ini variabel terkontrolnya adalah :

1. Pengujian menggunakan karburator

2. Pengujian menggunakan sepeda motor $125 \mathrm{cc}$ 4-tak dimodifikasi menjadi 6-tak.

3. Bahan bakar menggunakan pertamax .

\section{Waktu dan Tempat Penelitian}

Penelitian dilakukan pada periode Februari 2021 - selesai. Laboratorium Otomotif BBPPMPV BOE(VEDC) Malang .

\section{Alat dan Bahan Penelitian}

1. Prototype Motor Bakar 6 tak

2. Tachometer jonnesway Timing Light Advance Digital

3. Fan

4. Gas analyzer Technotest Mode 488

5. Pertamax

\section{Hasil dan Pembahasan}

Pengujian yang dilaksnakan memiliki tujuan untuk membandingkan kadar combustible species pada motor bakar 4 tak siklus otto dan motor bakar 6 tak siklus MUB-2 sehingga dapat menyimpulkan mekanisme motor 6 tak MUB-2 dapat bekerja dengan efektif untuk merubah combustible species yang tidak terbakar sempurna menjadi tenaga untuk mengekspansi kembali piston.

Pengujian Combustible Species Motor 4 tak Siklus Otto

Tabel 2 Hasil uji combustible species motor 4 tak konvensional

\begin{tabular}{cccccc}
\hline No & RPM & CO $(\%$ vol $)$ & HC $(\mathbf{p p m}$ vol $)$ & CO2 $(\%$ vol $)$ & $\boldsymbol{\lambda}$ \\
\hline 1. & 2400 & 0.44 & 105 & 0.9 & 0.890 \\
2. & 3000 & 0.90 & 107 & 1.7 & 0.852 \\
3. & 3600 & 1.00 & 91 & 2.4 & 0.861 \\
4. & 4200 & 1.17 & 88 & 2.0 & 0.841 \\
5. & 4800 & 1.02 & 72 & 2.0 & 0.865 \\
6. & 5400 & 1.00 & 63 & 2.4 & 0.884 \\
7. & 6000 & 0.79 & 55 & 3.2 & 0.922 \\
8. & 6600 & 0.80 & 44 & 3.1 & 0.921 \\
9. & 7200 & 0.89 & 38 & 3.6 & 0.925 \\
\hline
\end{tabular}

Pengujian Combustible Species Motor 6 tak Siklus MUB-2

Tabel 3 Hasil uji combustible species motor 6 tak MUB-2

\begin{tabular}{cccccc}
\hline No & RPM & CO $(\%$ vol $)$ & HC (ppm vol) & CO2 $(\%$ vol $)$ & $\boldsymbol{\lambda}$ \\
\hline 1. & 2400 & 0.89 & 91 & 1.5 & 0.853 \\
2. & 3000 & 0.87 & 83 & 1.8 & 0.860 \\
3. & 3600 & 0.76 & 67 & 1.5 & 0.862 \\
4. & 4200 & 0.56 & 56 & 0.5 & 0.828 \\
5. & 4800 & 0.75 & 49 & 1.8 & 0.899 \\
6. & 5400 & 1.08 & 41 & 1.4 & 0.821 \\
7. & 6000 & 0.83 & 39 & 1.9 & 0.916 \\
8. & 6600 & 0.72 & 30 & 2.1 & 0.902
\end{tabular}


Procedia of Engineering and Life Science Vol. 1. No. 2 Juni 2021

Seminar Nasional \& Call Paper Fakultas Sains dan Teknologi (SENASAINS 2nd)

Universitas Muhammadiyah Sidoarjo

\begin{tabular}{rrrrrr}
9. & 7200 & 0.66 & 26 & 2.3 & 0.924 \\
\hline
\end{tabular}

Dari data hasil pengujian di atas maka dibuat grafik perbandingan kadar combustible species pada motor 4 tak konvensional dan motor 6 tak MUB-2.

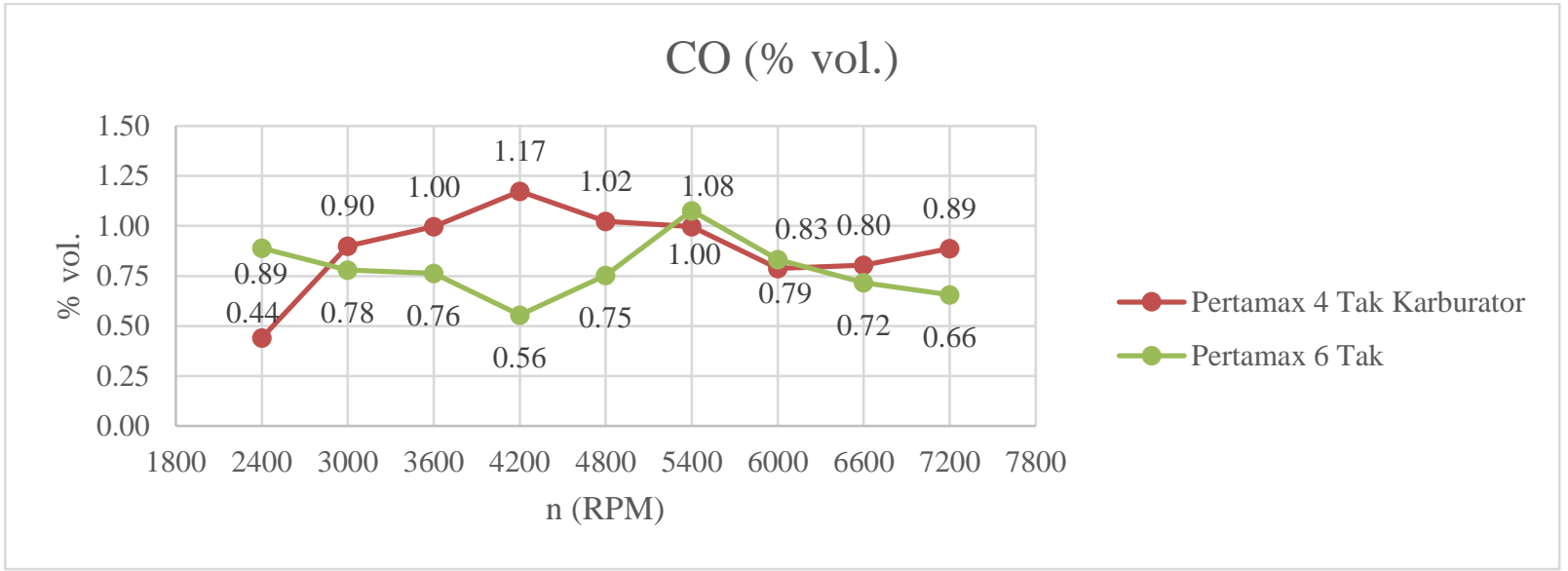

Gambar 5 Grafik kadar karbon monoksida dan putaran

Dari hasil pengujian menggunakan gas analyser, kadar karbon monoksida terendah yang dicapai oleh motor 6 tak MUB-2 adalah pada rpm 4200 sebesar 0,56 \%vol sedangkan pada motor 4 tak konvensionl 1,17 \%vol. Dari grafik yang ditunjukkan Gambar 5 diatas dapat disimpulkan bahwa motor 6 tak menghasilkan kadar karbonmonoksida lebih rendah dibandingkan dengan motor 4 tak konvensional. Dalam hal ini terjadi penurunan kadar karbon monoksida sebesar 12,36\%. Halini terjadi karena karbonmonoksida hasil pembakaran motor 4 tak konvensional dibakar kembali oleh motor 6 tak MUB-2 untuk dirubah menjadi energi untuk langkah ekspansi yang kedua.

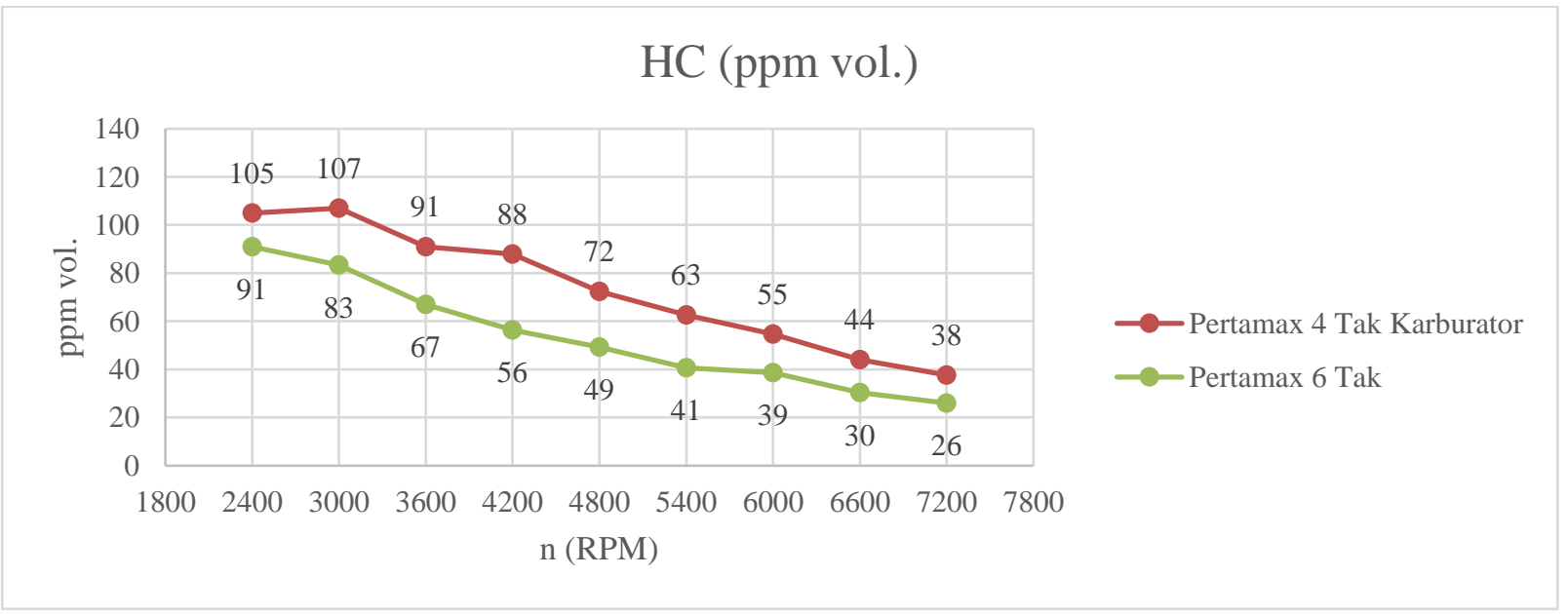

Gambar 6 Grafik kadar Hidrokarbon dan putaran

Dari hasil pengujian menggunakan gas analyser, kadar karbon monoksida terendah yang dicapai oleh motor 6 tak MUB-2 adalah pada rpm 7200 sebesar 26 ppm vol sedangkan pada motor 4 tak konvensionl 38 ppm vol. Dari grafik pada gambar 6 dapat disimpulkan bahwa motor 6 tak menghasilkan kadar hidrokarbon lebih rendah dibandingkan dengan motor 4 tak konvensional. Hal ini ditunjukan dengan adanya penurunain kadar Hidrokarbon pada motor 6 tak MUB-2 sebesar 27,30\%. Hal ini dipengaruhi oleh mekanisme motor 6 tak MUB-2 dengan dua kali durasi pembakaran dimana senyawa hidrokarbon yang belum terbakar sempurna pada motor 4 tak konvensional dibakar kembali oleh motor 6 tak MUB-2 untuk dirubah menjadi energi. Dapat dilihat bahwa semakin tinggi putaran mesin maka semakin rendah nilai hidrokarbon. 


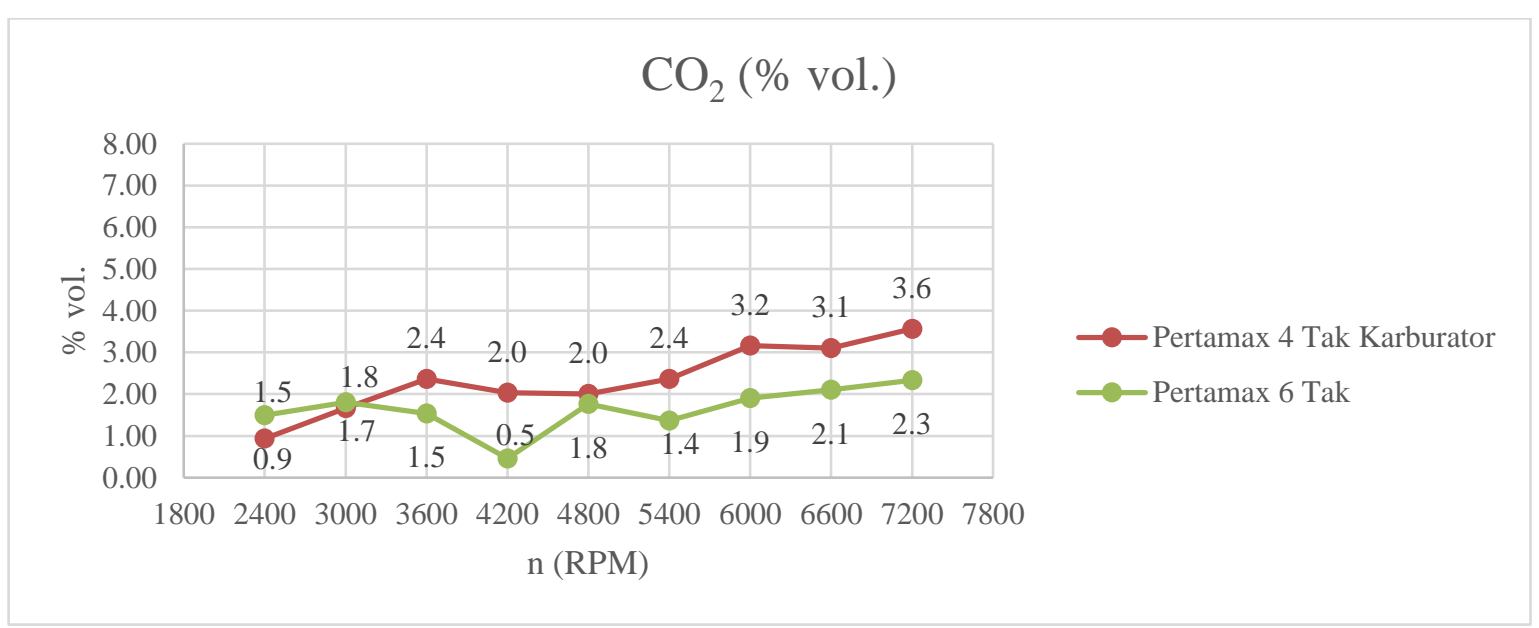

Gambar 7 Grafik kadar Karbondioksida dan putaran

Dari hasil pengujian menggunakan gas analyser, kadar karbondioksida terendah yang dicapai oleh motor 6 tak MUB-2 adalah pada rpm 4200 sebesar 0,5\%vol sedangkan pada motor 4 tak konvensionl 2,0 \%vol. Dari grafik diatas dapat disimpulkan bahwa motor 6 tak menghasilkan kadar karbondioksida lebih rendah dibandingkan dengan motor 4 tak konvensional. Terjadi penurunan kadar karbondioksida pada motor 6 tak MUB-2 sebesar 30,8\% . Kadar karbondioksida yang rendah disebabkan karena sis-sia pembakaran pada motor 4 tak dibakar kembali pada motor 6 tak MUB-2 untuk dirubah menjadi energi.

\section{Lambda}

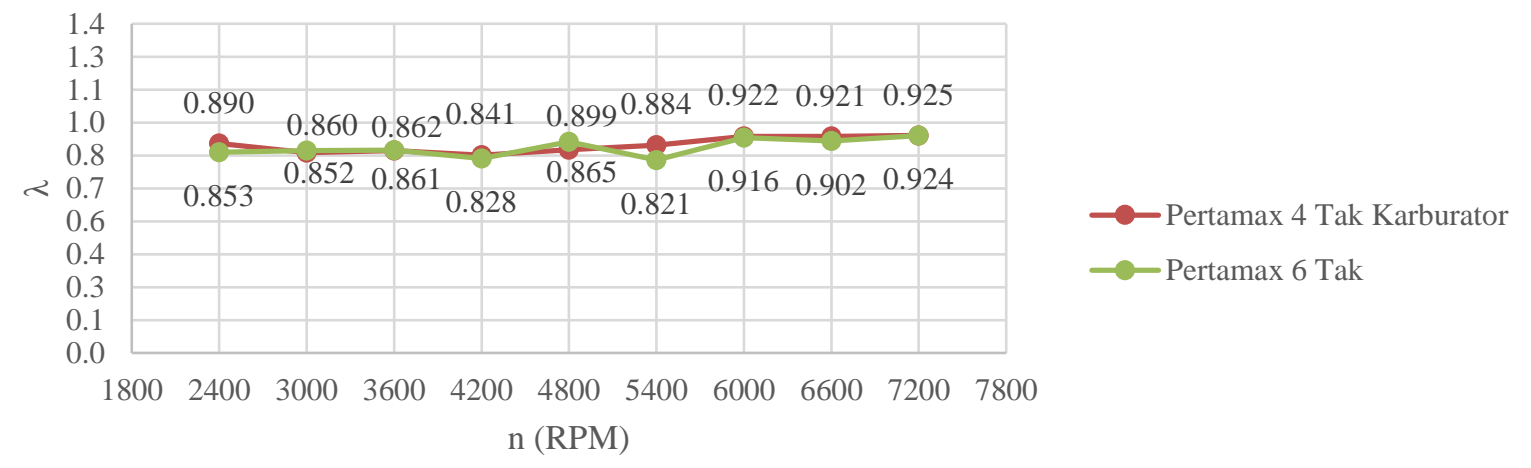

Gambar 8 Grafik nilai lambda dan putaran

Dari hasil pengujian menggunakan gas analyser nilai lambda dari motor 6 tak MUB-2 dan motor 4 tak hamper sama.Pada rpm 5400 nilai lambda pada motor 6 tak MUB-2 mengalami penurunan dengan nilai lambda sebesar 0,821 dan pada motor 4 tak konvensional sebesar 0,884. Ada penurunan nilai lambda pada motor bakar 6 tak-MUB2 sebesar $1,7 \%$.

\section{KESIMPULAN}

Berdasarkan hasil pengambilan data menggunakan metode eksperimental, hasil penelitian dan analisa Perbandingan kadar combustible species pada motor bakr 4 tak konvensional dan motor bakar 6 tak MUB-2 dengan menggunakan bahan bakar pertamax ,secara umum dapat disimpulkan bahwa, jika dilihat dari kadar combustible species pada motor bakar 6 tak MUB-2 lebih rendah daripada motor bakar 4 tak konvensional. Kandungan CO terndah terendah pada putaran $4200 \mathrm{rpm}$ sebesar 0,56\% \%ol, kadar hidrokarbon terndah pada putaran $7200 \mathrm{rpm}$ sebesar 26 ppm vol, kadar karbondioksida pada putaran $4200 \mathrm{rpm}$ sebesar 0,5\%vol dan nilai lambda yang relatif sama dengan motor 4 tak konvensional. Dengan dua kali durasi pembakaran pada mekanisme motor bakar 6 tak MUB-2 terjadi penurunan kadar karbonmonoksida sebesar 12,36\%, kadar hidrokarbon sebesar 27,30\%, kadar karbondioksida sebesar $30,8 \%$ dan nilai lambda sebesar $1,7 \%$. 


\section{UCAPAN TERIMA KASIH}

Saya ucapkan banyak terimakasih kepada:

1. Prof. Ir. Sudjito S, Ph. D. yang telah membimbing untuk menyusun tesis

2. Dr. Eng. Eko Siswanto, S.T., M.T. yang telah membimbing penyusunan tesis saya serta meminjamkan alat penelitian hak patennya berupa motor bakar 6 tak MUB-2

3. Kepala Kaboratorium Otomotif BBPPMPV BOE (VEDC).Malang beserta staf.

4. Bapak saya yang telah memberikan suport serta merestui saya .

5. Istri dan anak saya yang selalu mendoakan saya dan mendukung saya dalam melkasanakan perkuliahan dan pengerjaan tesis

6. Komandan Poltekad beserta Seluruh keluarga besar Poltekad Kodiklatad yang memberikan suport moril kepada saya dalam melaksnakan penelitian.

7. Mardiyono, S.T. selaku mekanik yang telah membantu saya merakit motor bakar 6 tak MUB-2

8. Syah Hadi Adios Dewonoto selaku mekanik yang telah membantu saya dalam mendesain Camshaft untuk motor bakar 6 tak MUB-2

9. Teman - teman yang sudah meluangkan waktunya untuk membantu saya pada saat penelitian dan pengambilan data.

\section{REFERENSI}

[1] Lili, Mulyatna., Yonik, Meilawati Yustiani., Ahmad, M. Sidik.” Uji Efektivitas Ionizer Bbm Terhadap Penurunan Emisi Gas Karbon Monoksida Dan Hidrokarbon Pada Mobil Dengan Sistem Karburator". Bandung : Universita Pasundan.2019

[2] Siswanto, Eko, D. Widhiyanuriyawan, A. S. Widodo, N. Hamidi, D. B. Darmadi and Sudjito. "On The Performance Of Six-Stroke Single-Power Combustion Engine". Journal of Heat and Mass Transfer 14:201218.2017.

[3] Arismunandar, Wiranto. "Penggerak Mula Motor Bakar Torak". Penerbit ITB.Bandung 2005

[4] Razi, Misru,. Siswanto, Eko., wijayanti, widya,. Pengaruh Derajat Pengapian Terhadap Kinerja Motor Bakar 6 Langkah Berbahan Bakar Etanol. Malang: JRM UB. eISSN 2477-6041 artikel 10, pp. 299-308, 2019

[5] Modul pengembangan keprofesian berkelanjutan PPPPTK BOE ,2018. Kode MDL-OTO.SM02.007.01

[6] Tri Susilo Wirawan, Ikram Anugrah, Suryanto, Musrady Mulyadi. "Analisis Bahan Bakar Bensin Terhadap Performansi Dan Nilai Ekonomi Motor Bensin Cm 11". Prosiding Seminar Hasil Penelitian (SNP2M) 2018 (pp.12-17) 978-602-60766-4-9

[7] Kurnia Dwi Artika, Rudiansyah."Pengaruh Penggunaan Bahan Bakar Premium Danpertalite Terhadap Emisi Gas Buang Sepeda Motor Empat Tak Satu Silinder 108 cc". Jurnal Elemen Volume 4 Nomor 2, Desember 2017. ISSN 2581-2661. 2017

[8] Peraturan Mentri negara Lingkungan Hidup Republik Indonesia No 23 Tahun 2012 tentang Baku Mutu emisi gas buang kendaraan bermotor tepe baru kategori L3

[9] Devianti .Muziansyah, Rahayu. Sulistyorini, Syukur. Sebayang. "Model Emisi Gas Buangan Kendaraan Bermotor Akibat Aktivitas Transportasi (Studi Kasus: Terminal Pasar Bawah Ramayana Koita Bandar)".JRSDD, Edisi Maret 2015, Vol. 3, No. 1, Hal:57 - 70 (ISSN:2303-0011) 2015

[10] Wardana, I. N. G. Bahan Bakar\&Teknologi Pembakaran. Malang: PT. Danar Wijaya-Brawijaya University Press -2008 